\title{
Review of Developing the Next Generation of Library Leaders
}

Amy B. Parsons

Columbus State University

Abstract: Review of Birrell, L. (2020) Developing the next generation of library leaders. Chicago, IL:

Association of College and Research Libraries.

Keywords: leadership, composite characters, semi-structured interviews, frequency analysis

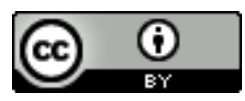

This is an Open Access article distributed under the terms of the Creative Commons Attribution 4.0 International License (http://creativecommons.org/licenses/by/4.0), which permits unrestricted use, distribution, and reproduction in any medium, provided the original work is properly cited. 
In her research for a doctorate in educational leadership, Lori Birrell explored career paths and leadership traits of librarians in senior positions in academic libraries. Birrell, explains that her doctoral dissertation research was the scaffolding for her book, "The Next Generation of Library Leaders." Birrell interviews 22 assistant deans in academic libraries. From these interviews, common traits and experiences came into focus along with variations in career paths to leadership. Birrell was able to create 4 composite characters from the original 22 interviews. The book expands on a set of guidelines and provides a framework for a strategic path for the next generation of librarians to be successful leaders. The first of seven chapters delves into her search in the literature.

The introduction relates that ten "big ideas" emerged from the body of research: A structure of ideas for a career ladder, dealing with identity crisis, theory and practice, support, finding your tribe, pause points, alternative leadership models, demystifying leadership, succession planning, and battling gender-based doubts (p. 4-6).

Chapter 1 examines the broader realm of library management and higher education. The author discovered that academic librarians' average age is older rather than younger. Very little data or literature exists showing that the older generation is preparing the next generation that will replace them. The author describes a leadership gap and a skills gap - this is evident from multiple surveys found in the literature. A practical tool in chapter one is the disclosure of words, terms, and phrases for desired skills and experiences. These are divided into hard skills, such as strategic planning and soft skills such as collaboration, and support. Knowing which skills to develop in employees and what language to describe in job postings and job descriptions is beneficial.

The methodology that was used is covered in Chapter 2. Birrell used semi-structured interviews and frequency analysis to focus her research. There were limitations to this method. Participants already think about and reflect on the topics she explored, and the method of open coding Journal of New Librarianship, 5(2020) pp. 200-203 10.21173/newlibs/9/20 
interviewing is a subjective process. In order to reconcile potential bias, the author worked with colleagues to review her analysis in early drafts of this book, making certain her data represented her observations. There were 22 senior leaders who self-identified as people with an interest in leadership and management.

Chapters 3 through 7 begin the personal narratives where the author describes real world examples through the voices of the 4 composite librarians. Each chapter is peppered with the " 10 big ideas" related data that was collected.

Chapter 3 shares the librarian's first experiences with leadership and supervision. Personal narratives are shared which describe situations where librarians first had to step up into leadership roles, whether they were just momentary situations or long term situations. Birrell uses these examples to describe transformational leadership moments.

Chapter 4 digs into deeper descriptions of skill development as the leaders advanced into more senior leadership roles. Librarians in leadership roles master a lot of skills in an organization. Birrell describes the complicated challenges of managing people; which, in my opinion, can be the most challenging and the most rewarding of all leadership skills. Communication and age differences between supervisors and supervisees are a few of the challenges that are discussed. Human resources and getting familiar with your organization's policies is very important as a leader. As leaders grow in their positions, the "hard skills" change from practical day to day skills to assessment, supervising, business and evidenced based skills (p.46).

Chapter 5 shares reflections on career paths. The librarians were asked what they would "do over" if they had the chance; as well as who was the most influential person in their careers. Positive managers provided good examples of what leadership should look like. The "do over" question is more complex. Some librarians lamented about the length of time it took to go back to school and Journal of New Librarianship, 5(2020) pp. 200-203 10.21173/newlibs/9/20 
pursue advanced degrees. They wished they had done it sooner. Some librarians wished they had more time to focus on research and publishing instead of administrative duties. All of the interviewees said the concept of a "good fit" was important when taking a position and also looking for employees to fill positions. "Fit" refers to a librarian's skill sets, interests, personality, and work/life balance (p.67).

In Chapter 6, the interviewees focus on ideas for preparing the next generation for leadership positions. Librarians must consider their motivations and think about "why" they want to be leaders. Several interviewees describe an identity crisis as they transitioned roles. The crisis stems from trying to balance the need to keep up practical skills of working librarians (an example - hours on the reference desk or teaching a class) with HR tasks and other manager/director type tasks.

Chapter 7 talks about career aspirations. One statement worth mentioning is that in order to become a library director you need to be able to envision yourself as one (p. 106). Another good point mentioned is that some individuals (closer to retirement age) see themselves as no longer climbing the career ladder, but rather helping build and mentor the next generations' careers.

In conclusion, Birrell explains in more detail the 10 "Big Ideas" that emerged from her research in library leadership. To summarize, leadership is needed at every level of an organization (p. 117). A scaffolding of all types of skills, both hard and soft, needs to be built and developed. Finding the balance between being a practitioner and a manager is essential. Fostering friendships throughout a career, mentoring, and developing a network is important. Other ideas to think about include: “leadership pause points" taking the time to reflect up on one's career milestones (p.119). Other big ideas include being creative with management models and sharing responsibilities, demystifying (p. 120) leadership and management, and planning for succession and battling gender-based doubts. All these "Big Ideas" are important issues to work on. 
The end of the book includes appendices that explain Birrell's methodology and includes the questions she used in her interviews. There are several pages of detailed endnotes and a bibliography. Our profession is aging and this information is timely. One piece that is lacking is exploring leadership development with diversity and inclusion especially in today's context with the Black Lives Matter (BLM) movement. BLM has brought to the forefront that the profession of librarianship needs to start making some real practical actionable changes.

As I write this review, we are living through one of the worst pandemic periods in decades. I admit the coronavirus pandemic and the Black Lives Matter movement of 2020 have both influenced and inspired my views when reading and reviewing this book. The coronavirus pandemic of 2020 has affected all parts of our society including academic libraries. Library staff need creative and courageous leaders to make difficult decisions at all times, but especially during periods of crisis. I see Lori Birrell's “Developing the Next Generation of Library Leadership” as an essential tool for academic librarians to continue to strengthen library leadership because she lays out in detail what we should be working on in a strategic and organized way and also makes it relatable with real world examples of library leadership. 